\title{
Chickpea genetic resources and its utilization in India: Current status and future prospects
}

\author{
Mohar Singh*, C. Bhardwaj ${ }^{1}$, Sarvjeet Singh ${ }^{2}$, Sweety Panatu, S. K. Chaturvedi ${ }^{3}$, J. C. Rana ${ }^{4}$, A. H. Rizvi ${ }^{5}$, \\ Neeraj Kumar ${ }^{1}$ and Ashutosh Sarker ${ }^{5}$
}

ICAR-National Bureau of Plant Genetic Resources, Regional Station, Shimla $171004 ;{ }^{1}$ Indian Agricultural Research Institute, Pusa Campus, New Delhi 110 012; ${ }^{2}$ Department of Plant Breeding \& Genetics, Punjab Agricultural University, Ludhiana 141 004; ${ }^{3}$ Indian Institute of Pulses Research, Kanpur 208 017; ${ }^{4}$ National Bureau of Plant Genetic Resources, Pusa New Delhi 110 012; ${ }^{5}$ The International Centre for Agricultural Research in Dry Area, South Asia and China Regional Programme, DPS Marg, Pusa Campus, New Delhi 110012

(Received: October 2016; Revised: November 2016; Accepted: November 2016)

\begin{abstract}
Chickpea is recognized as most nutritious pulse crop and with respect to acreage, it ranks at the top among pulses in India. Realizing the significance of plant genetic resources, special efforts were made by the National Bureau of Plant Genetic Resources (NBPGR) to collect the chickpea germplasm from different states of India including certain useful introductions from other countries. A large number of germplasm accessions including wild species were characterized and evaluated for various agro-morphological traits using chickpea minimal descriptor.Thus, extensive germplasm collections now exist in various gene banks of the world including India. As far as germplasm maintenance is concerned, a core set developed by ICRISAT comprising of 1956 accessions and mini core set of 211 accessions representing diversity for seed yield and its component traits. Further, core set developed by NBPGR consisting of 1103 accessions extracted from 14651 accessions conserved in the Indian National Gene Bank revealed that $70 \%$ of materials belong to Indian origin. The characterization and evaluation experiments of chickpea conducted across the country led to the registration of some unique germplasm accessions for different trait of interest. However, using crop wild relatives, several interspecific crosses and advance pre-breeding lines were developed by the pulse research institutions in India. The trait of interest incorporated especially from $C$. reticulatum, $C$. echinospermum and $C$. judaicum species for widening the genetic base of cultivated gene pool. Some pre-breeding lines have been suggested as useful donors in national chickpea crossing programmes.
\end{abstract}

Key words: Chickpea, genetic resources, prebreeding, utilization, documentation

\section{Introduction}

Chickpea (Cicer arietinum L.) is the most important grain legume crops in semi-arid tropics, especially, in the rainfed ecology of Indian sub-continent, Mediterranean regions, West Asian and North African areas, Eastern Africa and Latin America. It probably originated in South-Eastern Turkey and adjoining Syria, since most of the annual wild Cicer species are predominantly growing in these regions. Chickpea is a self-pollinating true diploid $(2 n=2 x=16)$ annual species with a genome size of $740 \mathrm{Mbp}$ (Arumuganathan and Earle, 1991). Domesticated chickpea (Cicer arietinum L.) has two distinct forms i.e., desi (small seeded, angular shape and coloured seeds with higher percentage of fibre) types and kabuli types (large seeded, owl's head shaped, beige coloured seeds with a low percentage of fibre). Chickpea seed contains protein, fiber, calcium, potassium, iron, phosphorus, magnesium, zinc, as well as substantial amount of selenium, sodium and copper, which make it nutritionally best composed edible dry legume for human consumption globally (Esha 2010). In Asia, it is the second most important grain legume after soybean, which contributes $86.73 \%$ of global pulse production from $89.89 \%$ area. The global area under chickpea is about 11.08 mha with a total production of $9.77 \mathrm{mt}$ and an average productivity of $882 \mathrm{~kg} / \mathrm{ha}$ (FAO, 2014). In India, chickpea is most important annual legume crop species in respect of both area and

\footnotetext{
*Corresponding author's e-mail: singhmohar2003@yahoo.com

Published by the Indian Society of Genetics \& Plant Breeding, F2, First Floor, NASC Complex, PB\#11312, IARI, New Delhi 110012 Online management by indianjournals.com; http://epubs.icar.org.in/journal/index.php/IJGPB
} 
production reaching to $9.93 \mathrm{mha}$ and $9.53 \mathrm{mt}$, respectively with a productivity of $960 \mathrm{~kg} / \mathrm{ha}$ during 2013-2014. The major chickpea growing states are, Madhya Pradesh, Uttar Pradesh, Andhra Pradesh, Rajasthan, Maharashtra, Gujarat and Karnataka, which covers over $95 \%$ area. Unfortunately, in terms of production and productivity of chickpea in the country is still low. Genetic improvement of chickpea is constrained due to non-availability of appropriate germplasm and narrow genetic base of varieties developed so far (Kumar et al. 2004). Conventional breeding led to the development of crop varieties with narrow genetic base which is evident from plateau in yield gains (Singh et al. 2014). Ascochyta blight epidemics caused by Ascochyta rabiei in North India in 1980 and 1982 (Singh et al. 1982, 1984) resulted in to severe losses in chickpea production. During the course of evolution, chickpea like other crops was subjected to genetic bottlenecks and subsequent founder effect that resulted in narrow genetic base. Thus, the progress achieved through conventional breeding for developing genetically superior varieties is not in pace with the current need of the country, which is evident from the stagnant productivity of chickpea during the past two decades (Varshney et al. 2010). On the other hand, plant genetic resources including crop wild relatives (CWRs) are the reservoir of useful genes/alleles for an array of major biotic and abiotic stresses including desirable agro-morphological traits, that provide basic raw materials for further genetic enhancement (Bains et al. 2012). Therefore, systematic exploration and collection of chickpea germplasm including wild species from diversity rich areas, their characteri-zation and evaluation, maintenance, conservation and utilization into the elite genetic backgrounds are of considerable significance in view of improving the chickpea production in the country.

\section{Origin, distribution, diversity and gene pool}

Chickpea has originated in an area of present-day South-eastern Turkey and Syria, where three wild annual Cicer species, C. bijugum, C. echinospermum and $C$. reticulatum, closely related to chickpea, are found. From here, chickpea spread with human migration towards West and South via the Silk Route (Singh et al. 1997). Four centers of diversity have been identified in the Mediterranean, Central Asia, the Near East and India, as well as a secondary centre of origin in Ethiopia (Vavilov 1951).

As far as distribution is concerned, the Cicer species occurs from sea level (e.g. C. arietinum, $C$. montbretii) to over $5000 \mathrm{~m}$ (C. microphyllum) near glaciers in the Himalayas. The cultivated species, C.arietinum is found only in cultivation and can not colonize without human intervention. The wild species e.g., C. reticulatum and C. bijugum occur in weedy habitats (fallow or disturbed habitats, road sides, cultivated fields of wheat, and other places not touched by man or cattle), mountain slopes among rubble (e.g. C. pungens, C. yamashitae), on forest soils, in broadleaf or pine forests (e.g. C. montbretii, C. floribundum), and also grown naturally in stony and desert areas of Himalayas in India (C. microphyllum) (Chandel 1984). The genus Cicer has 9 annual and 34 perennial species and is classified into three gene pools based on their compatibility with cultivated chickpea following (Harlan and de Wet 1971) the gene pool concept. The primary gene pool consists of domesticated chickpea, its landraces and the immediate progenitor species, $C$. reticulatum, the species which are easily crossable with cultivated chickpea with regular gene exchange. The secondary gene pool consists of $C$. echinospermum, a species that is crossable with cultivated chickpea, but with reduced pollen fertility of the resulting hybrids and their advance progenies. The tertiary gene pool consists of remaining six annual and 34 perennial species which are not readily crossable with cultivated chickpea and require specialized techniques for gene transfer into cultivated backgrounds of chickpea.

\section{Germplasm collection through exploration}

The basic aim of collecting germplasm is to capture the substantial amount of genetic variability in the smallest sample size (Singh and Singh 1997), and the first exploration mission led by the Regional Pulse Improvement of US Department of Agriculture (USDA) was undertaken during 1970s in India collecting 7000 chickpea accessions. Thereafter, the National Bureau of Plant Genetic Resources (NBPGR) took lead in conducting several exploration trips within the country in association with other national and international agencies. The area explored for the collection of chickpea germplasm comprised part of Rajasthan, Odhisa, Maharashtra, part of Gujarat, eastern parts of Arunachal Pradesh, Bihar, southern parts of Karnataka and Tamil Nadu (Singh and Singh 1997). Further, special efforts for exploration and collection of chickpea germplasm were made under the National Agricultural Technology Project (NATP) during 20002005. The bureau has also made explorations in collaboration with the International Crops Research 
Institute for Semi-arid Tropics (ICRISAT) Patancheru, to collect the germplasm from arid parts of Rajasthan, Bundelkhand region of Uttar Pradesh, Madhya Pradesh, Gujarat, Maharashtra and Telangana. However, a lot of interest has been generated in the wild Cicer species with the realization that they are the sound wealth of genes/alleles not only to biotic and abiotic stresses, but also for elite agromorphological traits (Van der Maesen and Pundir 1984). Many other explorations were also undertaken in the north-western Himalayan region to collect wild Cicer species. The bureau has collected some accessions of Cicer microphyllum from different ecological habitats, especially from Kukumseri, Triloki Nath, Throat and Mayar Valley in Lahaul and Lossar and Tabo in Spiti region of Himachal Pradesh. The International Crops Research Institute for Semi-Arid Tropics Patancheru has also made several collection missions in Afghanistan, Turkey, Syria and Pakistan and collected many samples of $C$. microphyllum, $C$. nuristanicum and $C$. macrocanthum species.

\section{Germplasm introduction and conservation}

Scientific activities on the introduction and conservation of genetic resources pertaining to agricultural crops for breeding purpose has been taken up after the classical work (Vavilov 1926) on the centres of origin and realization by plant breeders for its significance in genetic improvement. Chickpea, being an important pulse crop received due attention in the introduction and conservation of genetic resources in India. So far, 56,925 accessions including trial lines were introduced from 56 countries (Gautam et al. 2000).The International Centre for Agricultural Research in the Dry Areas (ICARDA), Syria has been an important source of introduction from where about 17,880 accessions of chickpea were introduced for their use in the national breeding programmes. Some promising exotic accessions were also introduced from Syria, USA, Spain, Australia, Bangladesh, Israel, Afghanistan and Greece. A set of 105 accessions of global wild annual Cicer species was also introduced from the Biodiversity and Integrated Gene Management Unit (BIGM) of ICARDA (Singh et al. 2014). However, R. S. Paroda gene bank at ICRISAT holds about 20,267 accessions including wilds (GCDT, 2014). The major chickpea germplasm including wild species preserved in ex-situ collections in different gene banks around the world are presented in Table 1. Chickpea has orthodox seeds, which can be dried and stored for a long period with a minimum loss of seed viability. For conservation purpose, accessions are assigned a national identity number, dried to seed-moisture of around $5 \pm 2$ per cent at $18^{\circ} \mathrm{C}$ and 15 per cent relative humidity. The accessions meeting international standards for their conservation, seed viability should be more than 85 per cent and quantity of about 2,000 seeds, are transferred to long-term storage (LTS) in the gene bank for future use.

\section{Germplasm characterization and evaluation}

Adequate characterization and evaluation for agromorphological traits is necessary to facilitate utilization of germplasm by breeders. To achieve this, a large number of germplasm accessions of chickpea have been characterized and evaluated in batches over the years in various institutions across India. The genetic variation ranges for some desirable traits namely, plant pigmentation (green to high pigmented), growth habit (erect, semi-erect, spreading, semi-spreading and prostrate), flower colour (blue, light blue, dark pink, pink, light pink, white and white-pink striped), seed coat colour (black, brown, light brown, dark brown, reddish brown, greyish brown, salmon brown, grey, brown beige, beige, yellow, light yellow, yellow brown, orange yellow, orange, yellow beige, ivory white, green, light green, variegated and black brown mosaic), plant height $(14-105 \mathrm{~cm})$, plant width $(13-124 \mathrm{~cm})$, days to flowering (33-107 days), flowering duration (13-75 days), days to maturity (84-169), number of pods/plant (2-238 pods), seeds/pod (1.0-3.2 seeds), seed weight (3.8-59 gm), seed shape (Angular, Owl's head, Pea shaped), seed testa texture (rough, smooth, tuberculated), seed yield (70-5130 kg/ha) and seed protein (12-29.6\%) (www.icrisat. org; (Narayan and Macefield 1976; Singh and Tuwafe 1980; Pundir et al. 1985; Teshale 1987; Arora and Tripathi 1991; Jana and Singh 1993; Shukla 1998). First large scale evaluation of chickpea germplasm for various agromorphological traits was taken up by Narayan and Macefield (1976). They evaluated 5,477 accessions for various yield attributing traits. This was followed by a no. of other relevant evaluations for resistance to major diseases. Elite genetic resources were identified for several biotic stresses viz., wilt (Satpute and Rao 1995; Halila and Strange 1997), Ascochyta blight (Muhammad et al. 1985; Wadud and Riaz 1988; Singh and Reddy 1993; Reddy et al. 1983), collar rot (Sugha et al. 1991), stunt (Shukla et al. 1985), root knot nematode (Gupta and Verma 1989), bruchids (Ahmad et al. 1995) and leaf miner (Singh and Weigand 1996). As far as maintenance of germplasm is concerned, ICRISAT has developed a core collection consisting of 1956 accessions and mini core set of 211 
Table 1. Chickpea germplasm holdings in different gene banks of the world

\begin{tabular}{|c|c|c|c|}
\hline Country/gene bank & Institution & $\begin{array}{l}\text { No. of wild } \\
\text { accessions }\end{array}$ & $\begin{array}{c}\text { No. of } \\
\text { cultivated } \\
\text { accessions }\end{array}$ \\
\hline Global gene bank & $\begin{array}{l}\text { International Crops Research Institute for Semi-Arid } \\
\text { Tropics (ICRISAT), Patancheru Hyderabad, India }\end{array}$ & 308 & 19959 \\
\hline Australia & Australian Temperate Field Crops Collection (ATFC) & 241 & 8414 \\
\hline Bangladesh & Bangladesh Agricultural Resources Institute (BARI) & - & 752 \\
\hline Brazil & Embrapa Hortalicas & - & 775 \\
\hline Canada & Agriculture and Agri-Food Canada & 2 & 507 \\
\hline Ethiopia & Institute of Biodiversity Conservation & - & 1173 \\
\hline Germany & Leibniz Institute of Plant Genetics and Crop Plant Research & 11 & 522 \\
\hline Greece & Fodder Crops and Pastures Institute & - & 445 \\
\hline Hungary & Institute for Agro Botany & 5 & 1165 \\
\hline India & National Bureau of Plant Genetic Resources & 241 & 14651 \\
\hline India & Regional Station, Akola & - & 813 \\
\hline Iran & Tehran University & - & 1200 \\
\hline Iran & National Plant Gene Bank of Iran & - & 5700 \\
\hline Japan & National Institute of Agrobiological Sciences & - & 682 \\
\hline Mexico & Instituto Nacional de Investigaciones Agricolas & - & 1600 \\
\hline Pakistan & Plant Genetic Resources Institute & 24 & 2122 \\
\hline Philippines & University of the Philippines & - & 407 \\
\hline Russian Federation & N.I. Vavilov All-Russian Scientific Research Institute of Plant Industry & - & 2091 \\
\hline Spain & $\begin{array}{l}\text { Instituto Nacional de Investigacion y TecnologiaAgraria y Alimentaria, } \\
\text { Centro de Recursos Fitogeneticos }\end{array}$ & - & 644 \\
\hline Spain & $\begin{array}{l}\text { Instituto Andaluz de Investigacion Agroalimentaria y Pesquera, } \\
\text { Centro de Investigacion y Formacion Agroalimentaria Cordoba }\end{array}$ & - & 608 \\
\hline Syrian Arab Republic & International Centre for Agricultural Research in Dry Areas & 270 & 13,192 \\
\hline Turkey & Plant Genetic Resources Department & 22 & 2054 \\
\hline Ukraine & Institute of Plant Production n.a. V.Y. Yurjev of UAAS & - & 1021 \\
\hline USA & $\begin{array}{l}\text { Western Regional Plant Introduction Station, USDA-ARS, Washington } \\
\text { State University }\end{array}$ & 202 & 6561 \\
\hline Uzbekistan & Uzbek Research Institute of Plant Industry & - & 1055 \\
\hline
\end{tabular}

Source: Global crop diversity trust (2014)

accessions (Upadhyaya et al. 2001). However, on the basis of allelic diversity data of global composite collection, a reference set of most diverse 300 accessions was also developed (Upadhyaya et al. 2008). Further, by using the core and mini core collections, various germplasm lines have been selected for agro-morphological traits, biotic and abiotic stresses at ICRISAT and other national chickpea improvement institutions the country. Furthermore, the NBPGR at New Delhi has also characterized 14651 accessions of chickpea and developed a core set of 1103 accessions using qualitative and quantitative data (Archak et al. 2016). Singh et al. (2014) characterized and evaluated a set of 88 wild annual Cicer accessions under two growing conditions of north-western India. The frequency distribution of seven annual Cicer species exhibited a wide range of intraspecific variation for some of the important morphological plant characteristics. Plant pigmentation showed variation in $C$. reticulatum, C. judaicum, and $C$. pinnatifidum 
along with lightly pubescent leaves, except $C$. yamashitae, where it was densely pubescent. Number of leaflets leaf ${ }^{-1}$ also showed remarkable variation in the majority of Cicer species except in $C$. yamashitae. Likewise, in most of the Cicer species, seed shape was angular, with the exception of $C$. arietinum and $C$. bijugum, which were irregular, rounded and pea shaped, respectively. Testa texture was rough in $C$. arietinum, C. reticulatum, C. judaicum, C. pinnatifidum, and $C$. yamashitae, and in $C$. echinospermum and $C$. bijugum, it was tuberculated of pattern. Substantial variation in seed color was observed in C. arietinum, C. reticulatum, C. judaicum, and $C$. pinnatifidum. The seed colour is black in $C$. echinospermum and $C$. yamashitae and brown in $C$. bijugum. The summary of evaluation of Cicer species against important agromorphological traits including major biotic and abiotic stresses is presented in Table 2 and Fig. 1.

\section{Germplasm diversity and characterization}

Molecular markers are very useful in elucidating the genetic diversity of germplasm and tagging genes of economic significance. Simon and Muehlbauer (1997) developed an integrated genetic linkage map of chickpea with 9 morphological, 27 isozyme, 10 RFLP and 45 RAPD markers covering the length of $550 \mathrm{cM}$. Ahmad (1999) and Sudupak et al. (2002) used Random Amplified Polymorphic DNA (RAPD) markers to study the genetic relationships among annual Cicer species and suggested that $C$. arietinum, $C$. reticulatum and $C$. echinospermum grouped in one cluster and $C$. yamashitae and $C$. chorassanicum in second cluster. However, C. pinnatifidum, $C$. bijugum and $C$. judaicum fell in third cluster and $C$. cuneatum is accommodated separately in fourth cluster.

Paucity of polymorphic molecular markers in chickpea has been a major limitation in the improvement of this important legume. Hence, in an attempt to develop sequence-tagged microsatellite sites (STMS) markers from chickpea, a microsatellite enriched library from the C. arietinum cv. Pusa 362 nuclear genome was constructed for the identification of CA/GT, and CT/GA, microsatellite motifs. A total of 92 new microsatellites were identified, of which 74 functional STMS primer pairs were developed by NIPGR, India. These markers were validated using 9 chickpea and one $C$. reticulatum accession. Further, cloning and sequencing of size variant alleles at two microsatellite loci revealed that the variable numbers of AG repeats in different alleles were the major source of polymorphism. Point mutations were found to occur both within and immediately upstream of the long tracts of perfect repeats, thereby bringing about a conversion of perfect motifs into imperfect or compound motifs. Such events possibly occurred in order to limit the expansion of microsatellites and also lead to the birth of new microsatellites. The microsatellite markers developed in this study will be useful for genetic diversity analysis, linkage map construction as well as for depicting intraspecific microsatellite evolution (Sethy et al. 2006).

At ICRISAT, SSR markers are being screened on a panel of 12 parental genotypes representing six intraspecific mapping populations derived from ICC $506 E B \times$ Vijay, ICC $3137 \times$ IG 72953, ICC $3137 \times$ IG 72933, ICC $283 \times$ ICC 8261, ICC $4958 \times$ ICC 1882, ICCV $2 \times$ JG 62 crosses and one interspecific ( $C$. arietinum $\times$ C. reticulatum) reference mapping population, ICC $4958 \times \mathrm{PI} 489777$ (Varshney et al. $2007)$. A total of $20,162(18,435$ high quality) droughtand salinity- responsive ESTs were generated from ten different root tissue cDNA libraries of chickpea (Varshney et al. 2009). BLASTN analysis of unique sequences with ESTs of four legume species (Medicago, Lotus, soybean and groundnut) and three model plant species (rice, Arabidopsis and poplar) provided insights on conserved genes across legumes as well as novel transcripts for chickpea. Of 2,965 (46.3\%) significant unigenes, only 2,071 (32.3\%) unigenes could be functionally categorised according to Gene Ontology (GO) descriptions. A total of 2,029 sequences containing 3,728 simple sequence repeats (SSRs) were identified and 177 new EST-SSR markers were developed. Besides SSR markers, 21,405 high confidence single nucleotide polymorphisms (SNPs) in 742 contigs (with $\geq 5$ ESTs) were also identified

Jain et al. (2013) generated a $520 \mathrm{Mb}$ draft genome sequence of $C$. arietinum using nextgeneration sequencing (NGS) platforms, bacterial artificial chromosome (BAC) end sequences and a genetic map to facilitate genetic improvement of chickpea varieties. Subsequently, Varshney et al. (2013) reported $\sim 738-\mathrm{Mb}$ draft whole genome sequence of $C$. arietinum for trait improvement, whose advanced version was later published by Parween et al. (2015). Patil and Kamble (2014) provided comparative protein profiling of wild chickpea and its induced mutants to assess genetic variation among mutants and parental genotypes. Further, a study of Khatodia et al. (2014) produced transgenic chickpea plants expressing cry1Aa3 gene, which showed resistance against Helicoverpa armigera, thus providing an opportunity 
Table 2. Sources of useful traits identified in Cicer species for introgression of useful traits into elite genetic background of chickpea

\begin{tabular}{|c|c|c|}
\hline Trait of interest & Cicer species & Reference \\
\hline \multicolumn{3}{|l|}{ Biotic stress } \\
\hline Ascochyta blight & $\begin{array}{l}\text { C. arietinum, C. judaicum, C. reticulatum, } \\
\text { C. montbretii, C. bijugam, C. pinnnatifidum, } \\
\text { C. cuneatum, C. echinospermum }\end{array}$ & $\begin{array}{l}\text { Vander Maesen and Pundir 1984; Singh and Reddy } \\
\text { 1993; Singh et al.1994; Singh et al. 1998; Pande et } \\
\text { 2010; Collard et al. 2001; Collard et al. 2003; Ahmad } \\
\text { et al. 2013; Shah et al. 2005; Pande et al. 2005; } \\
\text { Pande et al. 2006; Kaur et al. 2013; Singh et al. 2014; } \\
\text { Benzohra et al. 2014 }\end{array}$ \\
\hline Fusarium wilt & $\begin{array}{l}\text { C. arietinum, C. reticulatum, C. bijugam, } \\
\text { C. judaicum, C. pinnnatifidum, } \\
\text { C. echinospermum, C. cuneatum }\end{array}$ & $\begin{array}{l}\text { Nene et al. 1980; Vander Maesen and Pundir 1984; } \\
\text { Kaiser et al. 1994; Infantino et al. 1996; Nguyen et al. } \\
\text { 2004; Singh et al. 1994; Singh et al. 2005; Ahmad } \\
\text { et al. } 2013\end{array}$ \\
\hline Bruchids & C. reticulatum & Singh et al. 2010 \\
\hline $\begin{array}{l}\text { Botrytis grey } \\
\text { mould }\end{array}$ & $\begin{array}{l}\text { C. judaicum, C. bijugam, C. pinnnatifidum, } \\
\text { C. reticulatum }\end{array}$ & $\begin{array}{l}\text { Singh et al. 1982; Vander Maesen and Pundir 1984; } \\
\text { Haware et al. 1992; Pande et al. 2006; Basandrai et } \\
\text { al. 2006; Basandrai et al. 2008; Kaur et al. 2013; } \\
\text { Singh et al. } 2014\end{array}$ \\
\hline $\begin{array}{l}\text { Cyst nematode } \\
\text { resistance }\end{array}$ & C. bijugam, C. pinnnatifidum, C. reticulatum, & $\begin{array}{l}\text { Greco Di Vito 1993; Singh et al. 1994; Di Vito et al. } \\
\text { 1996; Ahmad et al. 2013; Singh et al. } 2010\end{array}$ \\
\hline Rust resistance & C. bijugam, C. reticulatum, C.echinospermum & Sillero and Alias 2012 \\
\hline $\begin{array}{l}\text { Root knot } \\
\text { nematode }\end{array}$ & $\begin{array}{l}\text { C. bijugum, C. judaicum, C. pinnnatifidum, } \\
\text { C. reticulatum, C. echinospermum }\end{array}$ & Singh et al. 2014 \\
\hline $\begin{array}{l}\text { Resistance to soil } \\
\text { borne diseases }\end{array}$ & $\begin{array}{l}\text { C. bijugum, C. cuneatum, C. judaicum, } \\
\text { C. pinnnatifidum }\end{array}$ & Reddy et al. 1991 \\
\hline $\begin{array}{l}\text { Phytophthora root } \\
\text { rot resistance }\end{array}$ & $\begin{array}{l}\text { C. reticulatum, C. bijugum, C. pinnnatifidum, } \\
\text { C. Echinospermum }\end{array}$ & Knights et al. 2008 \\
\hline $\begin{array}{l}\text { Root-lesion } \\
\text { nematodes }\end{array}$ & C. echinospermum, C. reticulatum, & Thompson et al. 2011 \\
\hline Stem rot & $\begin{array}{l}\text { C. reticulatum, C. pinnatifidum, C. judaicum, } \\
\text { C. yamashitae }\end{array}$ & Singh et al. 2007; Kaur et al. 2008 \\
\hline $\begin{array}{l}\text { Helicoverpa pod } \\
\text { borer tolerance }\end{array}$ & $\begin{array}{l}\text { C. bijugum, C. reticulatum, C. echinospermum, } \\
\text { C. cuneatum, C. pinnatifidum, C. Microphyllum }\end{array}$ & $\begin{array}{l}\text { Kaur et al. 1999; Sharma 2004; Sharma et al. } \\
2006\end{array}$ \\
\hline Leaf miner & $\begin{array}{l}\text { C. reticulatum, C. judaicum, C. bijugam, } \\
\text { C. cuneatum }\end{array}$ & $\begin{array}{l}\text { Singh and Weigand 1994; Singh et al. 1994; Singh } \\
\text { et al. } 2010\end{array}$ \\
\hline Seed beetle & $\begin{array}{l}\text { C. cuneatum, C. judaicum, C. reticulatum, } \\
\text { C. echinospermum }\end{array}$ & Gupta and Parihar 2015 \\
\hline \multicolumn{3}{|l|}{ Abiotic stress } \\
\hline Cold tolerance & $\begin{array}{l}\text { C. echinospermum, C.reticulatum, C. bijugum, } \\
\text { C. pinnnatifidum, C. judaicum }\end{array}$ & $\begin{array}{l}\text { Singh et al. 1990; Singh et al. 1994; Sandhu 2004; } \\
\text { Toker 2005; Berger et al. } 2005\end{array}$ \\
\hline Drought tolerance & $\begin{array}{l}\text { C. anatolicum, C. reticulatum C. microphyllum, } \\
\text { C. oxydon, C. montbrettii, C. pinnnatifidium, } \\
\text { C. songaricum, C. echinospermum }\end{array}$ & Toker et al. 2007; Canci and Toker 2009 \\
\hline \multicolumn{3}{|l|}{ Yield attributes } \\
\hline Yield attributes & C. reticulatum, C. pinnatifidum & $\begin{array}{l}\text { Jaswal and Singh 1989; Singh and Ocampo 1997; } \\
\text { Singh et al. 2005; Singh et al. 2012; Singh et al. } \\
2014\end{array}$ \\
\hline $\begin{array}{l}\text { High no. of seeds } \\
\text { plant }^{-1}\end{array}$ & C. cuneatum, C. montbretii & $\begin{array}{l}\text { Robertson et al. 1995; Robertson et al. 1997; Singh } \\
\text { et al. } 2014\end{array}$ \\
\hline
\end{tabular}



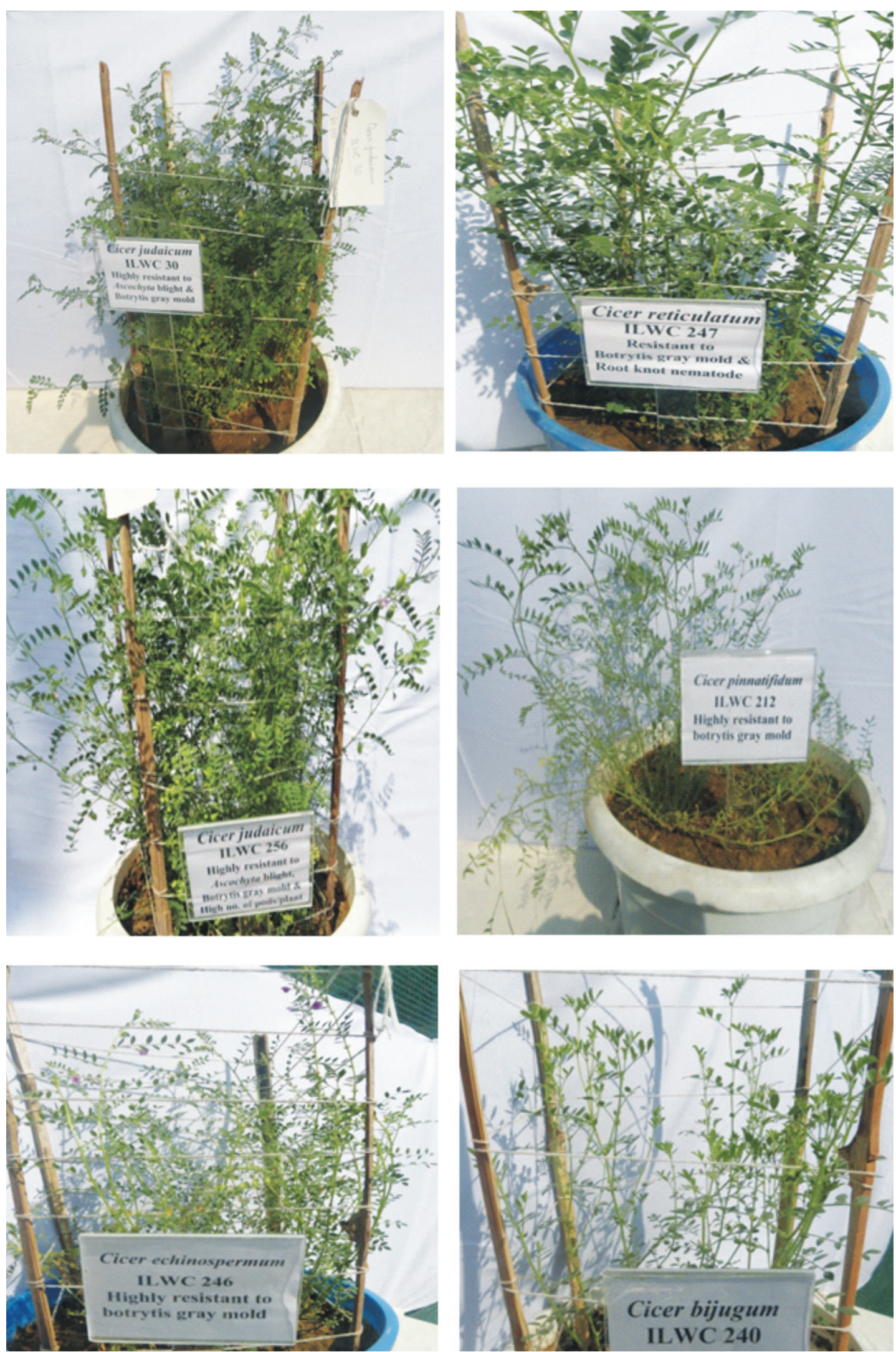

Fig. 1. Phenotyping and identification of promising accessions from the global wild annual Cicer collection for various traits of interest 
to reach field efficacy level. Although quantitative trait loci (QTLs) controlling agro-morphological traits in chickpea were identified, a genome-wide scanning of wild Cicer accessions was lacking until revealed by the study of Saxena et al. (2014) and Das et al. (2015). Upadhyaya et al. (2016) reported QTL analysis for delineation of candidate genes for marker-assisted selection. Moreover, studies of Saxena et al. (2014) on allelic diversity, genetic structure and linkage disequilibrium pattern in wild Cicer species and Gupta et al. (2015) on ESTs from C. arietinum that has provided expediency in genetics, genomics and breeding of chickpea germplasm. Khajuria et al. (2015), Kujur et al. (2015) and Bajaj et al. (2015) employed genome-wide polymorphic SSR and single nucleotide polymorphism (SNP) markers to extrapolate traitspecific genes, allelic diversity and domestication patterns in chickpea. Thereafter, Das et al. (2015) and Srivastava et al. (2016) made use of insertion-deletion (InDel) markers for improving chickpea yield by identifying QTLs for breeding purposes. Also, recent reports of Srivastava et al. (2016) and Gupta et al. (2016) on RNA-seq analysis of C. microphyllum and draft genome sequence of $C$. reticulatum, have opened new advances in agronomic trait improvement of chickpea.

\section{Genome mapping in chickpea}

International Chickpea Genome Sequence Consortium has completed genome sequencing of CDC Frontier, a kabuli variety (http://www.icrisat.org/gt-bt/lCGGC/ GenomeSequencing.htm). On the other hand ICC 4958, a desi landrace has been targeted and sequenced at NIPGR, New Delhi. In recent years, STMS markers were indeed applied for the generation of almost all published genetic maps of chickpea developed employing populations from crosses between $C$. arietinum and $C$. reticulatum, molecular marker based diversity and structural analysis (Bharadwaj et al. 2011a; Thudi et al. 2011; Choudhary et al. 2012; Subodh et al. 2015; Shefali et al. 2015). Several intra-specific mapping populations have also been used to identify the markers associated with traits like resistance to Fusarium wilt. Though, STMS markers were applied for the generation of almost all published genetic maps of chickpea, most genomic regions harbouring genes for important traits are not yet sufficiently saturated with co-dominant markers to apply MAS in plant breeding programs.

\section{Registration and documentation of germplasm}

Germplasm registration is an essential component for systematic and effective utilization in crop improvement programmes. The NBPGR has been designated as a nodal institute for germplasm registration. The first catalogue on chickpea, containing information on 25 descriptors of about 15,000 accessions was published by Pundir et al. (1998). Various germplasm accessions of chickpea have been registered at NBPGR, for specific characters: (1) IC 296691 (CGS 88101) with INGR number 98008 for salinity tolerance (2) IC 296738 (K850 LM), INGR13008 (GL84100) and INGR13009 (GL87045) for Ascochyta blight resistance; INGR number 99016 for multi-pinnate leaf with shorter internodes, (3) IC 296887 (H96-99) INGR 02003 for compact and tall plant type, (4) IC 296886 (EIOY(m) INGR 96008 for erect and dwarf growth habit, (5) IC 296430 (H-82-2(M) INGR 03031 for fast early vigor, early flowering and maturity with long internodes, (6) IC 395465 (chickpea mutant) INGR 03061 for fascinated broadened stem mutant, (7) IC 395466 (JMG-4) INGR 03062 to broad leaflets, (8) IC 395467 (OCW-JGM-5) INGR 03063 for curved flower, (9) IC 395468 (cymose inflorescence) INGR 03064 for mutant with cymose inflorescence, (10) IC573446 INGR 09108 for high yield dwarf and bushy type and (11) IC486088 INGR 13058 for upright podding and peduncle breeding behaviour.

\section{Pre-breeding and germplasm utilization}

Chickpea has intrinsically narrow genetic base in India. That limits plant breeder's progress today. The existing variability among indigenous germplasm has been exploited to reach to a maximum level of productivity. Wild Cicer species and exotic germplasm lines hold a wealth of useful alleles that, if we find them, can help in breaking yield barriers and enhance tolerance to array of stresses for stability (Labdi et al. 1996; Tayyar et al. 1996; Ahmad and Slinkard, 2003; Ahmad et al. 2005). However, systematic screening of wild Cicer collections by ICRISAT, Patancheru, IIPR Kanpur, IARI, New Delhi and NBPGR, New Delhi including some State Agricultural Universities (PAU, Ludhiana and MPKV, Rahuri Maharashtra) have prompted to initiate genetic base broadening activities. About 300 wild annual Cicer accessions and landraces have been characterized and evaluated for various agromorphological traits and biotic and abiotic stresses. Chickpea landraces and the wild species are the repertoire of the genes which provide tolerance to abiotic and biotic stresses. Thirty STMS primer pairs were used to dissect the genetic diversity and relationship of 14 wild and one cultivated accessions of chickpea by Shubha et al. (2011). The thirty five 
STMS primer pairs generated on an average 3.433 amplicons per primer pair. Polymorphic Information content (PIC) ranged from 0.246 to 0.775 and genetic similarity between cultivars ranged from 0.10 to 0.77 . Dendrogram constructed after STMS marker data showed four distinct clusters with a tendency of accessions of similar species clustering together. They inferred that the secondary gene pool is very diverse and could introduce wide variations if used in breeding. Bharadwaj et al. (2011) studying molecular diversity and phylogeny in a geographical collection of chickpea which included lines from ICRISAT and ICARDA gene banks inferred that the cultivated chickpea lines from ICRISAT which are of Indian origin were grouped together while the wild species and ICARDA lines which originated from West Asia and North Africa (WANA) formed a distinct group. They advocated that greater genetic gains could be achieved by crossing Indian lines with the landraces of WANA region. Studying the genetic diversity of the primary gene pool, Choudary et al. (2011) opined that most of the diversity existed in the wild species while the structure analysis revealed a low polymorphism for SSR markers in the cultivated lines. Tapan et al. (2015) inferred that chickpea incurs heavy yield losses due to terminal heat and drought as it is largely grown under rainfed restricted irrigated conditions on residual soil moisture. Exploring the extent of natural variation among cultivated chickpea for drought tolerance is important to develop prebreeding and breeding strategies for chickpea. Thirty seven landraces representing seven countries and fourteen provinces obtained from ICARDA and three bold seeded kabuli varieties each from IIPR Kanpur and MPKVV, Rahuri were evaluated for their Relative Water Content (RWC) and Membrane Stability Index (MSI), the established physiological parameters for drought tolerance. The analysis into MSI has indicated wide variability in the landraces for drought tolerance. RWC followed a similar pattern to MSI. The genotypes that were having higher MSI also had higher RWC indicating the soundness of the traits. The genotypes viz., IG5844a, 5856, 5867, 5884, 5887, 5894, 5896, 5906 and 5908 were found tolerant to drought based on RWC and MSI values and were proposed to be donors for drought tolerance.

Wild Cicer species and landraces possess substantial amount of genetic diversity and resistance to Fusarium wilt in C. reticulatum, $C$. echinospermum, C. pinnatifidum and C. judaicum (Nene and Haware, 1980; Singh et al. 1994; Kaiser et al. 1994; Infantino et al. 1996; Stamigna et al. 1998; Singh et al. 1998;
Singh et al. 2005); Ascochyta blight resistance in $C$. reticulatum, $C$. echinospermum, $C$. bijugum and $C$. cuneatum (Singh et al. 1982; Singh and Reddy, 1993; Collard et al. 2001; Singh et al. 2014). Likewise, Botrytis grey mould resistance in C. bijugum (Singh et al. 1994; Kaur et al. 2013; Singh et al. 2014) and Cyst nematode resistance in $C$. reticulatum and $C$. bijugum (Singh et al. 1989; Singh and Reddy, 1991). Bruchid (seed beetle) resistance in C. pinnatifidum, $C$. echinospermum and C. reticulatum (Singh et al. 1994; Singh et al. 1998). Among abiotic stresses, cold tolerance in C. judaicum, C. bijugum and $C$. microphyllum (Chandel 1984; Sillero and Alias; 2012; Singh et al. 2007) and drought tolerance in $C$. microphyllum (Toker et al. 2007; Canci and Toker 2009). Further, overall performance for most of the abiotic stress resistance has been reported in $C$. bijugum, C. pinnatifidum and C. judaicum (Singh et al. 1994 and Singh et al. 1998). As far as utilization of wild Cicer species is concerned, several interspecific crosses have been attempted between Cicer arietinum and its annual wild relatives. There has been no report of successful hybridization between a perennial Cicer species and Cicer arietinum. Thus, interspecific hybrids between Cicer arietinum $x$ Cicer reticulatum and Cicer arietinum $\times$ Cicer echinospermum have been successfully attempted by several workers (Verma et al. 1990). Verma et al. (1990) made large number of crosses between cultivated as female parent and Cicer reticulatum, C. echinospermum, C. judaicum, C. bijugum and $C$. pinnatifidumas male parents. They suggested the overall success rate of seed set $1.69 \%$. However, other interspecific crosses have also been made at Indian Institute of Pulses Research, Kanpur, Indian Agricultural Research Institute, New Delhi and National Bureau of Plant Genetic Resources, New Delhi; Punjab Agriculture University, Ludhiana and Mahatma Phule Krishi Vidya Peeth, Rahuri and incorporated useful trait of interest. Certain pre-breeding lines have been developed from interspecific crosses at IIPR, Kanpur and PAU, Ludhiana (Singh et al. 2012). Among them, IPC71 (Cicer arietinum $x$ Cicer judaicum) has been used as donor parent under National Chickpea Crossing Program. Singh et al. (2015) also attempted interspecific crosses and the study revealed a high level of heterosis for number of podsplant ${ }^{-1}$ and seed yieldplant ${ }^{-1}$ in $\mathrm{F}_{1}$ generation. Three cross-combinations of Pusa 1103 x ILWC 46, Pusa 256 x ILWC 46 and Pusa 256 x ILWC 239 exhibited substantially higher variability for important yield-related traits.

The International Crops Research Institute for 
Semi-Arid Tropics, Patancheru has led to the release of more than 50 genotypes directly as cultivars in various countries like, Australia, Algeria, Bangladesh, Cyprus, Ethiopia, India, Italy, Myanmar, Nepal, Oman, Syria, Sudan, Turkey and USA (http://ICRISAT.org.). Long back local germplasm was directly used for the development of cultivars to meet the immediate requirement. The most important varieties are Chaffa, Dohad yellow, BDN 9-3, Annegeri-1, JG 315, JG 74, Pragati and BG 287 and these selections are still popular in many parts of India. Thereafter, variability created through hybridization between germplasm accessions having desired characters and the widely adapted genotypes has been utilized. Further, Kumar et al. (2004) suggested that out of 126 chickpea released cultivars in the past four decades, in which most frequently used parental lines were PB7, IP58, F8 and S26. Therefore, narrow genetic diversity among modern released cultivars rendering them more vulnerable to array of stresses and adaptation. About 16 chickpea cultivars were developed from the best use of exotic germplasm for desirable traits like, bold seed, wider adaptation, Ascochyta blight resistance, drought tolerance and early maturity. Where, Pusa 261 was developed by utilizing P827 from Morocco and P9847 from Russia in a two-way cross approach. Likewise, Pusa 244 and Pusa 267 were developed from three-way cross including two exotic parents with one indigenous cultivar. However, pedigree analysis of all chickpea released cultivars revealed the use of only 87 accessions indicating insignificant part of germplasm utilization in chickpea breeding in India.

\section{Future perspectives}

The productivity of chickpea is compounded by narrow genetic base, biotic and abiotic stresses. The evaluation and identification of wild Cicer species will greatly aid in trait discovery. With the use of modern molecular tools and pre-breeding activities some useful traits can be introgressed in to cultivars, which can be further used to augment the yield of chickpea. The earlier studies indicated the usefulness of exploiting existing variability for broadening the genetic base in chickpea both at phenotypic and molecular levels. Since, most of the desirable gene complexes are present in non-crossable secondary and tertiary pools, there is an urgent need to augment germplasm collections in the primary gene pool and landraces. An identification of areas is required for further exploration and targeted trait specific collections particularly from WANA regions. Collaborative efforts among national and international research institutions would help the evaluation of chickpea germplasm systematically at hot spot centers.

\section{Declaration}

The authors declare no conflict of interest.

\section{References}

Ahmad F. 1999. Random amplified polymorphic DNA (RAPD) analysis reveals genetic relationships among the annual Cicer species. Theor. Appl. Genet., 98: 657-663.

Ahmad F. and Slinkard A. E. 2003. Limitations to bridge species facilitated alien gene transfers in chickpea pre-fertilization events. J. Genet. Breed., 23: 45-49.

Ahmad F., Gaur P. M. and Croser J. 2005. Chickpea; In: Singh R. J. and Jauhar P. P. (ed): Genetic Resources, chromosome engineering, and crop improvement, Grain Legu., CRC Press, USA, 1: 187-217.

Ahmad R., Lal S. S., Yadav C. P. and Sachan J. N. 1995. Screening of chickpea germplasm against Bruchid infestation during storage. Indian J. Pulses Res., 8: 102-103.

Ahmad S. Khan M. A. Sahi S. T. and Ahmad R. 2013. Evaluation of chickpea germplasm against Ascochyta rabiei (pass) lab. J. Ani. Plant Sci., 23: 440-443.

Archak S., Tyagi R. K., Harer P. N., Mahase L. B., Singh N., Dahiya O. P., Abdul Nizar M., Singh M., Talukar V., Kumar V., Dutta M., Singh N. P. and Bansal K. C. 2016. Characterization of chickpea germplasm conserved in the Indian National Gene Bank and development of core set using qualitative and quantitative data. The Crop J., 4: 417-424.

Arora P. P. and Tripathi K. N. 1991. Evaluation of chickpea germplasm for yield and its components. Indian $\mathrm{J}$. Pulses Res., 4: 89-90.

Arumuganathan K. and Earle E. D. 1991. Nuclear DNA content of some important plant species. Plant Mol. Biol., Report. 9: 208-218.

Bains N. S., Singh S., Gill M. S. and Dhillon B. S. 2012. Enhanced utilization of plant genetic resources for crop improvement. Ind. J. Plant Genet. Resour., 25: 77-87.

Bajaj D., Das S., Badoni S., Kumar V., Singh M., Bansal K. C., Tyagi A. K. and Paridha S. K. 2015. Genomewide high-throughput SNP discovery and genotyping for understanding natural (functional) allelic diversity and domestication patterns in wild chickpea. Scientific Reports, 5: 12468.

Basandrai A. K., Macleod W. J., Siddique K., Pande S. and Payne P. 2006. Evaluation of wild chickpea germplasm against Australian isolates of Botrytis cinerea the casual organism of Botrytis grey mold of chickpea. BGM Newsl. 
Basandrai A. K., Pande S. and Basandrai D. 2008. Recent advance in host-parasite interaction, chickpea Ascochyta rabaie and Botrytis cinerea systems; In: Setia R. C., Nayyar H. and Setia N. (Ed): Crop Improvement, Strategies and Applications, IK International, New Delhi India, 265-301.

Benzohra I. K., Bendahmane B. S., Benkada M. Y. and Labdi M. 2014. Evaluation of wild Cicer species for resistance to three pathotype of Ascochyta rabiei (Pass.) Labr. in Algeria. Afr. J. Microbiol. Res., 8(20): 2022-2029.

Berger J. D., Buck R., Henzell J. M. and Turner N. C. 2005. Evolution in the genus Cicer-vernalization response and low temperature pod set in chickpea ( $C$. arientum L.) and its wild relatives. Australian J. Agric. Res., 56: 1191-1200.

Bharadwaj C., Chauhan S. K., Shubha Yadav, Tara Satyavathi C., Rakesh Singh, Kumar J., Rachana Srivastava and Gayatri Rajguru. 2011b. Molecular marker-based linkage map of chickpea (Cicer arietinum) developed from desi $\times$ kabuli cross. Indian Journal of Agricultural Sciences, 81(2): 116-18.

Bharadwaj C., Srivastava R., Chauhan S. K., Satyavathi C. T., Kumar J., Faruqui A., Yadav S., Rizvi A. H. and Kumar T. 2011a. Molecular diversity and phylogeny in geographical collection of chickpea (Cicer sp.) accessions. J. Genet., 90: e94-e100.

Canci H. and Toker E. C. 2009. Evaluation of annual wild Cicer species for drought and heat resistance under field conditions. Genet. Resour. Crop Evol., 56: 1-6.

Chandel K. P. S. 1984. A note on the occurrence of wild $C$. microphyllum Benth. and its nutrient status. Intl. Chickpea Newsl., 10: 4-5.

Choudhary P., Khanna S. M., Jain P. K., Bharadwaj C., Kumar J., Lakhera P. C. and Srinivasan R. 2012. Genetic structure and diversity analysis of the primary gene pool of chickpea using SSR markers. Genetics and Molecular Research, 11: 891-905.

Choudhary P., Khanna S. M., Jain P. K., Bharadwaj C., Kumar J., Lakhera P. C. and Srinivasan R. 2013. Molecular characterization of primary gene pool of chickpea based on ISSR markers. Biochem. Genet., 51(3-4): 306-322.

Collard B. C. Y., Ades P. K., Pang E. C. K., Brouwer J. B. and Taylor P. W. J. 2001. Prospecting for sources of resistance to ascochyta blight in wild Cicer species. Aust. Plant Path., 30: 271-276.

Collard B. C. Y., Pang E. C. K. and Taylor P. W. J. $2003 a$. Selection on wild Cicer accessions for the generation of mapping population segregating for resistance to Ascochyta blight, Euphytica, 130: 1-9.

Collard B., Ades P., Pang E., Brouwer J. and Taylor P. 2001. Prospecting for sources of resistance to Ascochyta blight in wild Cicer species. Australas. Plant Pathol., 30: 271-276.
Das S., Upadhyaya H. D., Bajaj D., Kujur A., Badoni S., Laxmi, Kumar V., Tripathi S., Gowda C. L. L., Sharma S., Singh S., Tyagi A. K. and Parida S. K. 2015. Deploying QTL-seq for rapid delineation of a potential candidate gene underlying major trait-associated QTL in chickpea. DNA Research, 22: 193-203.

Das S., Upadhyaya H. D., Srivastava R., Bajaj D., Gowda C. L. L., Sharma S., Sube S., Tyagi A. K. and Paridha S. K. 2015. Genome-wide insertion-deletion (InDel) marker discovery and genotyping for genomicsassisted breeding applications in chickpea. DNA Research, 22: 377-386.

Esha food data base 2010. The World's Healthiest Foods. www.whfoods.org. Salem, Oregon: ESHA Foundation.

FAO 2010.http://faostat.fao.org/site/567/desktopdefault. aspx?pageid=567.

Gautam P. L., Sharma G. D., Srivastava U., Singh B. B., Kumar A., Saxena R. K. and Srinivasan K. 2000. 20 glorious years of NBPGR, New Delhi, India, 333.

Global crop diversity trust.2014. http://www.croptrust.org/ main/

Greco N. and Di Vito M. 1993. Selection for nematode resistance in cool season food legumes; In: Singh K. B. and Saxena M. C. (Eds.): Breeding for Stress Tolerance in Cool Season Food Legumes, ICARDA, Chichester, UK, 157-164.

Gupta D. C. and Verma K. K. 1989. Reaction of germplasm and studies on avoidable yield losses in chickpea due to root knot nematodes, Meloidogyne javanica. Harayana Agric. Univ. J. Res., 19: 318-320.

Gupta S., Garg V. and Bhatia S. 2015. A new set of ESTs from chickpea ( $C$. arietinum $L$.) embryo reveals two novel F-Box genes, CarF-box_PP2 and CarFbox_LysM, with potential roles in seed development. PLoS One, 10: e0121100.

Gupta S., Kumar T., Verma S., Bharadwaj C. and Bhatia S. 2015. Development of gene-based markers for use in construction of the chickpea (Cicer arietinum L.) genetic linkage map and identification of QTLs associated with seed weight and plant height. Molecular Biology Reports, 42(11): 15711580.

Gupta S., Nawaz K., Parween S., Roy R., Sahu K., Pole A. K., Khandal H., Srivastava R., Parida S. K. and Chattopadhyay D. 2016. Draft genome sequence of $C$. reticulatum $\mathrm{L}$., the wild progenitor of chickpea provides a resource for agronomic trait improvement. DNA Res., 1-10.

Halila M. H. and Strange R. N. 1997. Screening of Kabuli chickpea germplasm for resistance to Fusarium wilt. Euphytica, 96: 273-279.

Harlan J. R. and de Wet J. M. T. 1971. Toward a Rational Classification of Cultivated Plants. Taxon, 20: 509517. 
Haware M. P., Nene Y. L., Pundir R. P. S. and Rao J. N. 1992. Screening of world chickpea germplasm for resistance to Fusarium wilt. Field Crops Res., 30: 147-154.

http://www.icrisat.org/ what we do/crop/chickpea/ pfirst.asp).

Infantino A., Porta-Puglia A. and Singh K. B. 1996. Screening wild Cicer species for resistance to fusarium wilt. Plant Dis., 80: 42-44.

Jain M., Misra G., Patel R. K., Priya P., Jhanwar S., Khan A. W., Shah N., Singh V. K., Garg R., Jeena G., Yadav M., Kant C., Sharma P., Yadav G., Bhatia S., Tyagi A. K. and Chattopadhyay D. 2013. A draft genome sequence of the pulse crop chickpea (C. arietinum L.). The Plant J., 74: 715-729.

Jaiswal H. K. and Singh B. D. 1989. Analysis and gene effects for yield traits in crosses between $C$. arietinum and $C$. reticulatum. Indian J. Genet., 49: 9-17.

Jana S. and Singh K. B. 1993. Evidence of geographical divergence in Kabuli chickpea from germplasm evaluation data. Crop Sci., 33: 626-632.

Kaiser W. J., Alacala-Jimenez A. R., Hervas-Vargas A., Trapero-Casas J. L. and Jimenez-Diaz R. M. 1994. Screening of wild Cicer species for resistance to races 0 and 5 of Fusarium oxysporum $f$. sp. ciceris. Plant Dis., 78: 962-967.

Kalia C. S., Singh M. P. and Kundalia S. K. 1981. Some observations on induced variability in chickpea ( $C$. arietinum L.). Pulse Crops Newsl., 1: 19.

Kaur L., Sirarii A., Kumar D., Sandhu J. S., Singh S., Kapoor K., Singh I., Gowda C. L. L., Pande S., Gaur P., Sharma M., Imtiaz M. and Siddique K. H. M. 2013. Combining Ascochyta blight and Botrytis grey mold resistance in chickpea through inter-specific hybridization. Phytopathologia mediterranea, 52(1): 157-165.

Kaur L., Tripathi H. S., Vishwa D., Reddy M. V., Singh G. and Kharkwal M. C. 2008. Management of diseases in food legumes. In Proceeding of the fourth Int. Food Legumes Res. Confer., New Delhi India, 1: 608-637.

Kaur S., Chhabra K. S. and Arora B. S. 1999. Incidence of Helicoverpa armigera on wild and cultivated species of chickpea. Intl. Chickpea and Pigeon pea Newsl., 6: 18-19.

Khajuria Y. P., Saxena M. S., Gaur R., Chattopadhyay D., Jain M., Paridha S. K. and Bhatia S. 2015. Development and integration of genome-wide polymorphic microsatellite markers onto a reference linkage map for constructing a high-density genetic map of chickpea. PLoS One, 10: e0125583.

Khan S. and Wani M. R. 2005. Effect of diethyl sulphate on chickpea, C. arietinum. Bionotes, 7(2): 55-59.

Khan S., Wani M. R., Bhat M. and Parveen K. 2005. Induced chlorophyll mutations in chickpea ( $C$. arietinum L.). Intl. J. Agri. Bio., 7: 764-767.

Khatodia S., Kharb P., Batra P., Kumar P. A. and Chowdhury V. K. 2014. Molecular characterization of Bt chickpea ( $C$. arietinum L.) plants carrying cry1Aa3 gene. Intl. J. Curr. Microbiol. Appl. Sci., 3: 632-642.

Knights E. J., Southwell R. J., Schwinghamer M. W. and Harden S. 2008. Resistance to Phytopthoraa medicaginis Hansen and Maxwell in wild Cicer species and its use in breeding root resistance chickpea (C. arietinum L.). Australian J. Agric. Res., 59: 383-387.

Kujur A., Bajaj D., Upadhyaya H. D., Das S., Ranjan R., Shree T., Saxena M. S., Badoni S., Kumar V., Tripathi S., Gowda C. L. L., Sharma S. and Tyagi A. K. 2015. Employing genome-wide SNP discovery and genotyping strategy to extrapolate the natural allelic diversity and domestication patterns in chickpea. Frontiers in Plant Sci., 6: 162.

Kumar S., Gupta S. and Singh B. B. 2004. How wide the genetic base of pulse crops is: Pulses in new perspective; In: Ali M., Singh B. B., Kumar S. and Dhar V. (Ed.): Proceedings of the National Symposium on Crop Diversification and Natural Resources Management Kanpur, India, 221-217.

Kumar T., Bharadwaj C., Rizvi A. H., Sarker A., Tripathi S., Alam A. and Chauhan S. K. 2015. Chickpea landraces: a valuable and divergent source for drought tolerance. International Journal of Tropical Agriculture, 33(2 (Part II)): 633-638.

Labdi M., Robertson L. D., Singh K. B. and Charrier A. 1996. Genetic diversity and phylogenetic relationships among the annual Cicer species as revealed by isozyme polymorphism. Euphytica, 88: 181-188.

Muhammad B., Alam S. S. and Qureshi S. H. 1985. Chickpea germplasm evaluation for resistance to Ascochyta blight under artificial conditions. Intl. C. Newsl., 12: 24-26.

Narayan R. K. J. and Macefield A. J. 1976. Adaptive responses and genetic divergence in a world germplasm collection of chickpea (C. arietinum L.) Theor. Appl. Genet., 47: 179-187.

Nene Y. L. and Haware M. P. 1980. Screening chickpea for resistance to wilt. Plant Dis., 64: 379-380.

Nguyen T. T., Taylor P. W. J., Redden R. J. and Ford R. 2004. Genetic diversity in Cicer using AFLP analysis. Plant Breed., 123: 173-179.

Pande S., Kishore G. K., Upadhyaya H. D. and Rao J. N. 2006. Identification of sources of multiple disease resistance in mini-core collection of chickpea. Plant Dis., 90: 1214-1218.

Pande S., Sharma M., Gaur P. M. and Gowda C. L. L. 2010. Host Plant Resistance to Ascochyta Blight of 
Chickpea. Information Bull. No. 82. Project Report: Intl. Crop Res. Inst. for the Semi-Arid Tropics.

Pande S., Siddique K. H. M., Kishore G. K., Bayaa B., Gaur P. M., Gowda C. L. L., Bretag T. W. and Crouch J. H. 2005. Ascochyta blight of chickpea (C. arietinum L.). A review of biology, pathogenicity and disease management. Aust. J. Agric. Res., 56: 317-33.

Parween S., Nawaz K., Roy R., Pole A. K., Venkata S., Misra G., Jain M., Yadav G., Paridha S. K., Tyagi A. K., Bhatia S. and Chattopadhay D. 2015. An advanced draft genome assembly of a desi type chickpea ( $C$. arietinum L.). Scientific Reports, 5: 12806.

Patil A. S. and Kamble G. C. 2014. Comparative protein profiling study in wild chickpea and its induced mutants. The Expt., 18: 1297-1303.

Pundir R. P. S., Rao K. N. and Van Der Maesen L. J. G. 1985. Distribution of qualitative traits in the world germplasm of chickpea $C$. arietinum L. Euphytica, 34: 697-703.

Reddy M. V., Hussain S. A., Malik B. A. and Singh K. B. 1983. Relative reaction of some chickpea desi germplasm lines to Ascochyta blight in Pakistan and Syria. Intl. C. Newsl., 8: 24-25.

Reddy M. V., Raju T. N. and Pundir R. P. S. 1991. Evaluation of wild Cicer accessions to wilt and root rots. Indian Phytopathol., 44: 388-391.

Robertson L. D., Ocampo B. and Singh K. B. 1997. Morphological variation in wild annual Cicer species in comparison to the cultigen. Euphytica, 95: 309319.

Robertson L. D., Singh K. B. and Ocampo B. 1995. A catalog of annual wild Cicer species. ICARDA, Aleppo, Syria.

Salimath P. M., Toker C., Sandhu J. S., Kumar J., Suma B., Yadav S. S. and Bahl P. N. 2007. Conventional breeding methods. Chickpea breeding and management. CAB International, Wallingford, 369390.

Sandhu J. S. 2004: Pers. Communication, Punjab Agric. Univ., Ludhiana, Punjab.

Sarvjeet S., Gumber R. K., Joshi N. and Singh K. 2005. Introgression from wild Cicer reticulatum to cultivated chickpea for productivity and disease resistance. Plant Breed., 124: 477-480.

Satpute G. and Rao S. K. 1995. Screening of Kabuli gram (C. arietinum L.) germplasm for vascular wilt resistance. Legu. Res., 18: 3-4.

Saxena M. S., Bajaj D., Das S., Kujur A., Kumar V., Singh M., Bansal K. C.,Tyagi A. K. and Paridha S. K. 2014. An integrated genomic approach for rapid delineation of candidate genes regulating agro-morphological traits in chickpea. DNA Research, 1-16.

Saxena M. S., Bajaj D., Kujur A., Das S., Badoni S., Kumar V., Singh M., Bansal K. C., Tyagi A. K. and Paridha S.
K. 2014. Natural allelic diversity, genetic structure and linkage disequilibrium pattern in wild chickpea. PLoS One, 9: e107484.

Sethy N. K., Shokeen B., Edwards K. J. and Bhatia S. 2006. Development of microsatellite markers and analysis of intraspecific genetic variability in chickpea (Cicer arietinum L.). Theoretical and Applied Genetics, 112(8): 1416-1428.

Shah T. M., Hassan M., Haq M. A., Atta B. M., Alam S. S. and Ali H. 2005. Evaluation of Cicer species for resistance to Ascochyta Blight. Pak. J. Bot., 37(2): 431-438.

Sharma H. C. 2004. A Little Help from Wild: Exploiting Wild Relatives of Chickpea for Resistance to Helicoverpa armigera. ICRISAT, Patancheru, India.

Sharma H. C., Bhagwat M. P., Pampapathy G., Sharma J. P. and Ridsdill-Smith T. J. 2006. Perennial wild relatives of chickpea as potential sources of resistance to Helicoverpa armigera. Genet. Resour. Crop Evol., 53: 131-138.

Shukla A. 1988. Association among quantitative traits in chickpea germplasm. Indian J. Pulses Res., 1: 5056.

Shukla A., Pandya B. P. and Tripathi H. S. 1985. Response of chickpea germplasm to natural incidence of stunt disease. Intl. C. Newsl., 12: 26-27.

Sillero J. C. and Alias I. M. 2012. Identification and characterization of resistance to rust (Uromyces ciceris-arietini (Grognot) Jacz. \& Boyd) in a germplasm collection of Cicer spp. Euphytica, 188: 229-238.

Simon C. J. and Muehlbauer F. J. 1997. Construction of a chickpea linkage map and its comparison with maps of pea and lentil. J. Hered., 88: 115-119.

Singh A. K., Singh R. V., Bharti R. C., Chandra N., Kumar C. and Dimreee S. K. 2010. Introduction of wild and weedy relatives of crop plants in India. Environ. Ecol., 28: 1715-1721.

Singh G., Kapoor S. and Singh K. 1982. Screening of chickpea for Grey Mold Resistance. Intl. Chickpea Newsl., 7: 13-14.

Singh G., Singh K. and Kapoor S. 1982. Screening for sources of resistance to Ascochyta blight of chickpea. Intl. Chickpea Newsl., 6: 15-17.

Singh G., Verma M. M., Gill A. S., Sandhu T. S., Brar H. S., Sra S. S. and Kapoor S. 1984. Screening of gram varieties against Ascochyta blight. Crop Improv., 11: 153-154.

Singh K. B. and Ocampo B. 1997. Exploitation of wild Cicer species for yield improvement in chickpea. Theor. Appl. Genet., 95(3): 418-423.

Singh K. B. and Reddy M. V. 1991. Advances in disease resistance breeding in chickpea. Adv. Agron., 45: 191-222. 
Singh K. B. and Reddy M. V. 1993. Resistance to six races of Ascochyta rabiei in the world germplasm collection of chickpea. Crop Sci., 33: 186-189.

Singh K. B. and Reddy M. V. 1993. Sources of resistance to Ascochyta blight in wild Cicer species. Netherlands J. Plant Path., 99: 163-167.

Singh K. B. and Singh O. 1997. Prospects of creating higher yield potential in chickpea; In: Asthana A. N. and Ali M. (Eds.): Recent Advances in Pulses Research, ISPRD, Indian Inst. of Pulses Res., Kanpur, India, 66-88.

Singh K. B. and Tuwafe S. 1980. The collection, evaluation and maintenance of Kabuli chickpea germplasm of ICARDA. Intl. C. Newsl., 2: 4-5.

Singh K. B. and Weigand S. 1994. Identification of resistant sources in Cicer species to Liriomyza cicerina. Genet. Res. Crop Evol., 41: 75-79.

Singh K. B. and Weigand S. 1996. Registration of three leaf miner resistant chickpea germplasm lines: ILC3800, ILC5901 and ILC7738. Crop Sci., 36: 472.

Singh K. B., Hawtin G. C., Nene U. L. and Reddy M. V. 1981. Resistance in chickpea to Ascochyta rabiei. Plant Dis., 65: 586-587.

Singh K. B., Holly L. and Bejiga G. 1991. A catalogue of Kabuli Chickpea Germplasm, an evaluation report of winter-sown kabuli chickpea land races, breeding lines, and wild Cicer species. ICARDA, Syria. 393397.

Singh K. B., Malhotra R. S. and Saxena M. C. 1995. Additional sources of tolerance to cold in cultivated and wild Cicer species. Crop Sci., 35: 1491-1497.

Singh K. B., Malhotra R. S., Halila M. H., Knights E. J. and Verma M. M. 1994. Current status and future strategy inbreeding chickpea for resistance to biotic and abiotic stresses. Euphytica, 73: 137-149.

Singh K. B., Malthotra R. S. and Saxena M. C. 1990. Sources on tolerance to cold in Cicer species. Crop Sci., 30: 1136-1138.

Singh K. B., Ocampo B. and Robertson L. D. 1998. Diversity for abiotic and biotic resistance in the wild annual Cicer species. Genet. Res. Crop Evol., 45: 9-17.

Singh K. B., Pundir R. P. S., Robertson L. D., van Rheene H. A., Singh U., Kelley T. J., Rao P. P., Johansen C. and Saxena N. P. 1997. Chickpea; In: Fuccillo D., Sears L., and Stapleton P. (Ed.): Biodiversity in Trust, Cambridge Univ. Press, 100-113.

Singh K. B., Vito M. D., Greco N. and Saxena M. C. 1989. Reaction of wild Cicer spp. lines to Heterodera ciceri. Nematologia mediterranea, 17(2): 113-114.

Singh M., Bisht I. S., Dutta M., Kumar K., Basandrai A. K., Kaur L., Sirari A., Khan Z., Rizvi A. H., Sarkar A. and Bansal K. S. 2014. Characterization and evaluation of wild annual Cicer species for agro-morphological traits and major biotic stresses under North western
Indian conditions. Crop Sci., 54: 229-239.

Singh M., Kumar K., Bisht I. S., Dutta M., Rana M. K., Rana J. C., Bansal K. C. and Sarker A. 2015. Exploitation of wild annual Cicer species for widening the gene pool of chickpea cultivars. Plant Breed., 134: 186192

Singh R. P., Singh I., Singh S. and Sandhu J. S. 2012. Assessment of genetic diversity among interspecific derivatives of $C$. arietinum with $C$. pinnatifidum. J. Food Legu., 25(2): 150-152.

Singh S., Singh I., Kapoor K., Gaur P. M., Chaturvedi S. K., Singh N. P. and Sandhu J. S. 2014. Chickpea; In: Singh M., Bisht I. S. and Dutta M. (Ed.): Broadening the Genetic Base of Grain Legumes, Springer, India, 51-73.

Srivastava R., Bajaj D., Malik A., Singh M. and Parida S. K. 2016. Transcriptome landscape of perennial wild Cicer microphyllum uncovers functionally relevant molecular tags regulating agronomic traits in chickpea. Scientific Reports, 6.

Srivastava R., Singh M., Bajaj D. and Parida S. K. 2016. A high-resolution InDel (Insertion-Deletion) markersanchored consensus genetic map identifies major QTLs governing pod number and seed yield in chickpea. Frontiers in Plant Sci., 7: 1362.

Stamigna C., Mancinelli R., Crino P., Infantino A., PortaPuglia A. and Saccardo F. 1998. Multiple resistances to diseases in wild relatives of chickpea (C. arietinum L.). In 'Opportunities for high quality, healthy and added value crops to meet European demands. Proceedings of the 3rd European Conference on Grain Legumes (AEP)'. Valladolid, Spain. 221-222.

Sudupak M. A., Akkaya M. S. and Kence A. 2002. Analysis of genetic relationships among perennial and annual Cicer species growing in Turkey using RAPD markers. Theor. Appl. Genet., 105: 1220-1228.

Sugha S. K., Sharma B. K. and Tyagi P. D. 1991. Screening of chickpea germplasm for resistance to collar rot caused by Sclerotium rolfsiis acc. Legu. Res., 14: 191-192.

Tayyar R., Federici C. V. and Waines G. J. 1996. Natural outcrossing in chickpea (C. arietinum L.) Crop Sci., 36: 203-205.

Teshale A. 1987. Characterization of Ethiopian chickpea germplasm. PGRC-E-ILCA Germplasm Newsl., 16: 15-20.

Thompson J. P., Reen A. R., Clewett T. G., Sheedy J. G., Kelly A. M., Gogel B. J. and Knights E. J. 2011. Hybridization of Australian chickpea cultivars with wild Cicer spp. increases resistance to root-lesion nematodes (Pratylenchus thornei and P. neglectus). Australasian Plant Pathol., 40: 601-611.

Thudi M., Bohra A., Nayak S. N., Varghese N., Shah T. M., Penmetsa R. V., Nepolean T., Srivani G., Gaur P. M., 
Kulwal P. L., Upadhyaya H. D., Kavi Kishor P. B., Winter P., Kahl G., Town C. D., Kilian A., Cook D. R. and Varshney R. K. 2011. Novel SSR markers from BAC-end sequences, DArT arrays and a comprehensive genetic map with 1,291 marker loci for chickpea (Cicer arietinum L.). PLoS ONE 6: e27275.

Toker C. 2005. Preliminary screening and selection for cold tolerance in annual wild Cicer species. Genet. Resour. Crop Evol., 52: 1-5.

Toker C., Canci H. and Yildirim T. 2007. Evaluation of perennial wild Cicer species for drought resistance. Genet. Resour. Crop Evol., 54: 1781-1786.

Upadhyaya H. D., Bajaj D., Narnoliya L., Das S., Kumar V., Gowda C. L. L., Sharma S., Tyagi A. K. and Paridha S. K. 2016. Genome-wide scans for delineation of candidate genes regulating seedprotein content in chickpea. Frontiers in Plant Sci., 7: 302.

Upadhyaya H. D., Bramel P. J. and Singh S. 2001. Development of a chickpea core subset using geographical distribution and quantitative traits. Crop Sci., 41: 206-210.

Upadhyaya H. D., Dwivedi S. L., Varshney R., Hoisington D. and Singh S. 2008. Genetic structure, diversity and allelic richness in composite collection and reference set in chickpea. BMC Plant Biol., 8: 1-12.

Van der Maesen L. J. and Pundir R. P. S. 1984. Availability and use of wild Cicer germplasm. FAO/IBPGR Plant Genet. Resour. Newsl., 57: 19-24.

Van der Maesen L. J. G. 1987. The chickpea; In: Saxena M. C. and Singh K. B. (Ed.): Origin, history and taxonomy of chickpea, CAB Int. Wallingford, U.K. 1134.

Varshney R. K., Hiremath P. J., Lekha P. T., Kashiwagi J., Balaji J., Deokar A. A., Vadez V., Xiao Y., Srinivasan R., Gaur P. M., Siddique K. H. M., Town C. D. and Hoisington D. A. 2009. A comprehensive resource of drought- and salinity-responsive ESTs for gene discovery and marker development in chickpea (Cicer arietinum L.). BMC Genomics, 10: 523.

Varshney R. K., Hoisington D. A., Upadhyaya H. D., Gaur P. M., Nigam S. N., Saxena K., Vadez V., Sethy N. K., Bhatia S., Aruna R., Gowda M. V. C. and Singh N. K.
2007. Molecular genetics and breeding of grain legume crops for the semi-arid tropics. In 'Genomicsassisted crop improvement. Vol II. Genomics applications in crops'. (Eds. R. K. Varshney, R. Tuberosa) pp. 207-242. (Springer: The Netherlands).

Varshney R. K., Nayak S. N., May G. D. and Jackson S. A. 2010. Legume genomics and breeding. Plant Breed. Review, 33: 257-304.

Varshney R. K., Song C., Saxena R. K., Azam S., Yu S., Sharpe A. G., Cannon S., Baek J., Rosen B. D., Taran B., Millan T., Zhang X., Ramsay L. D., Iwata A., Wang Y., Nelson W., Farmer A. D., Gaur P. M., Soderlund C., Penmesta R. V., Xu C., Bharti A. K., He W., Winter P., Zhao S. et al. 2013. Draft genome sequence of chickpea (C. arietinum) provides a resource for trait improvement. Nature Biotech., 31: 240-248

Vavilov N. I. 1951. The origin, variation, immunity and breeding of cultivated plants. Chronica Botanica, 13: 1-366.

Vavilov N. I. 1926. Studies on the origin of cultivated plants. Bulletin Applied Botany Genet. Plant Breed., 16: 1248.

Verma M. M., Sandhu J. S., Brar H. S. and Brar J. S. 1990. Crossability studies in different species of Cicer (L.). Crop Imprv., 17: 179-181.

Verma S., Gupta S., Bandhiwal N., Kumar T., Bharadwaj C. and Bhatia S. 2015. High-density linkage map construction and mapping of seed trait QTLs in chickpea (Cicer arietinum L.) using Genotyping-bySequencing (GBS). Scientific reports, 5.

Vishnu-Mittre A. 1974. The beginning of agriculture-pale botanical evidence in India; In: Hutchinson J. B. (ed): Evolutionary Studies on World Crops: Diversity and Change in the Sub-Continent, Cambridge: Cambridge Univ. Press.

Wadud A. and Riaz M. 1988. Screening of desi chickpea germplasm for resistance to Ascochyta blight in Pakistan. Intl. C. Newsl., 18: 17-19.

Yadav S., Bharadwaj C., Chauhan S. K., Rizvi A. H., Kumar J. and Satyavathi C. T. 2011. Analysis of genetic diversity in Cicerspecies using molecular markers. The Indian Journal of Genetics and Plant Breeding, 71(3): 272-275. 